\title{
nate \\ Positive Interactions Drive Bat Distribution in a Remote Oceanic Archipelago (Azores, Portugal)
}

\author{
Ana Rainho (1D)
}

Citation: Rainho, A. Positive Interactions Drive Bat Distribution in a Remote Oceanic Archipelago (Azores, Portugal). Diversity 2022, 14 , 17. https://doi.org/10.3390/ d14010017

Academic Editor: Michael Wink

Received: 23 November 2021 Accepted: 24 December 2021 Published: 29 December 2021

Publisher's Note: MDPI stays neutral with regard to jurisdictional claims in published maps and institutional affiliations.

Copyright: (C) 2021 by the author Licensee MDPI, Basel, Switzerland. This article is an open access article distributed under the terms and conditions of the Creative Commons Attribution (CC BY) license (https:// creativecommons.org/licenses/by/ $4.0 /)$
cE3c-Centre for Ecology, Evolution and Environmental Changes, Departamento de Biologia Animal, Faculdade de Ciências, Universidade de Lisboa, 1749-016 Lisbon, Portugal; amrainho@fc.ul.pt

\begin{abstract}
One of the fundamental interests in ecology is understanding which factors drive species' distribution. We aimed to understand the drivers of bat distribution and co-occurrence patterns in a remote, insular system. The two bat species known to occur in the Azores archipelago were used as a model. Echolocation calls were recorded at 414 point-locations haphazardly distributed across the archipelago. Calls were analysed and assigned to each species. Binominal generalised linear models were adjusted using different descriptors at two scales: archipelago and island. The presence of the co-occurring species was included at both scales. The results show that island isolation, habitat and climate play an essential role on the archipelago and island scales, respectively. However, the positive interaction between bat species was the most critical driver of species' distribution at the island scale. This high co-occurrence pattern at the island scale may result from both species' maximising foraging profit in a region where prey abundance may be highly variable. However, further research is necessary to clarify the mechanisms behind this positive interaction. Both species are threatened and lack specific management and protection measures. Maintaining this positive interaction between the two species may prove to be fundamental for their conservation.
\end{abstract}

Keywords: Azores; bats; biotic interactions; ecological modelling

\section{Introduction}

One of the fundamental interests in ecology is understanding which factors and processes drive species' occurrence in space. This knowledge stands as the basis of several research lines and supports the conservation and management of species and habitats worldwide [1]. Many studies made use of both the ecological niche theory and habitat suitability modelling to predict and map species distributions in relation to biotic (e.g., vegetation type or land use) and abiotic (e.g., climate) factors [2]. However, it is increasingly recognised that species' occurrence may also depend on biotic interactions, such as predation, competition or symbiosis [3-5]. Biotic interactions have received less attention due to the methodological challenges they carry when considering complex communities, even if it has been shown that accounting for such interactions greatly improves the performance and predictive power of species distribution models [6-8].

It is often easier to analyse ecological patterns in relatively simplified ecosystems, such as islands, where few interacting species exist. Studies of insular systems have important ramifications for conservation biology because they provide insights into mechanisms that lead to species persistence, loss or coexistence. Moreover, insular species are often endemic and have smaller populations, most vulnerable to extinctions either by human pressures, invasive species or climate change, often requiring the most urgent conservation efforts [9-11].

The Azores archipelago (Figure 1) has two bat species currently confirmed: the Azorean bat (Nyctalus azoreum) endemic to the Azores [12] and the Madeiran Pipistrelle bat (Pipistrellus maderensis) endemic to the Macaronesia [13]. The Azorean bat is known to occur in seven of the archipelago's nine islands, being relatively abundant in all but one-Santa Maria [14,15]. N. azoreum has unique features separating it from its continental 
counterpart, Nyctalus leisleri. These include a smaller size [12,16] and higher peak frequency of echolocation calls (avg. $32.1 \mathrm{kHz}$; [14]). Additionally, it is often found foraging during the day [17]. The Azorean bat seems to have colonised the archipelago naturally during the Holocene by a single matrilineage. Bats reached both central and oriental groups of islands, but the over-sea distance proved to be enough to isolate the bat populations of the two groups of islands [18,19]. Pipistrelle bats were recorded in several islands [14,20], but their identity was only confirmed as P. maderensis by mitochondrial DNA analysis at Santa Maria [13]. Although the morphology and echolocation characteristics of the Pipistrelle bats observed suggest that the same species may occur in other islands $[13,14]$, there is no confirmation, and therefore, it will be referred here as P. cf. maderensis. In the Azores, P. cf. maderensis is rare or very rare in all the islands where it was located-even on Santa Maria, where it is more common [14].

Due to their small and fragmented populations and decline in their habitat quality, both species are classified as Critically Endangered in the Azores [21] and as Vulnerable globally [22,23]. Understanding the drivers of distribution and patterns of occurrence for these species is thus crucial for their conservation.
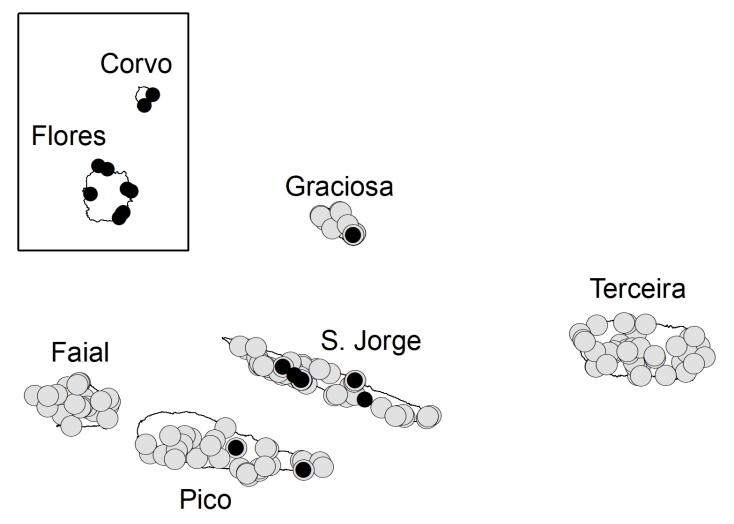

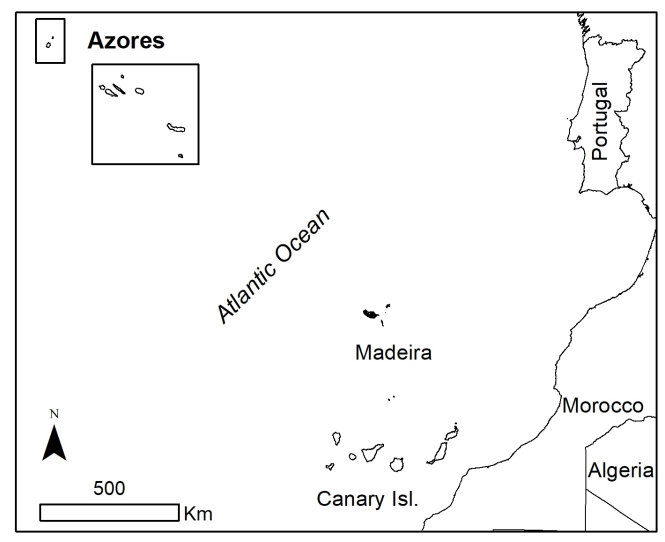

S. Miguel
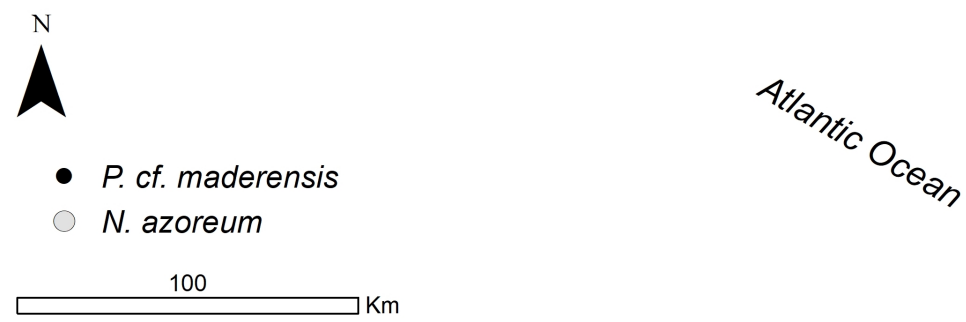

St ${ }^{\text {a Maria }}$

Figure 1. Map of the Azores islands with the known distribution of N. azoreum and P. cf. maderensis in the archipelago. The right-side upper panel shows the location of the Azores in context with western Europe and Africa and the Canary and Madeira Islands. Refer to this panel for the correct location of the islands of Flores and Corvo.

A bat survey focusing on the western and eastern groups of islands (Figure 1) was completed by 2002, confirming (1) the presence of $P$. cf. maderensis in the western group and Santa Maria, (2) the apparent absence of N. azoreum in Flores and Corvo and (3) the co-occurrence of the two bat species in Santa Maria [14]. An additional survey performed in São Jorge (central group) in 2003 confirmed P. cf. maderensis in a single location of this island (own data). The overall lack of information about both species' distribution and pattern of co-occurrence raised the questions and hypotheses that were tested during this study: 
1. The occurrence of each bat species on different islands of the archipelago is driven by island characteristics (archipelago scale).

MacArthur and Wilson [24] argued that immigration to and extinction from each island were directly related to island size and isolation. The relationship between island area and species' occurrence may result from different mechanisms, all favouring larger islands that (a) support larger populations and are less prone to local extinctions, (b) usually have higher habitat diversity and (c) are larger targets for colonising individuals [25]. Island isolation will depend on both the distance from a source population and the dispersal capability of the studied species, and although bats can be potent flyers, it is recognised that crossing large stretches of open water is an important deterrent to these animals $[19,26,27]$. Intra-archipelagic isolation can also be relevant as it may influence species' progression while colonising different islands or the population persistence on a given island due to the "rescue effect" of immigrant individuals from populations established on nearby islands $[25,28]$. As predicted by the general dynamic model island, age and geodynamics should also have an essential role in island colonisation and extinction patterns [28]. However, these processes are poorly known in the Azores (but see [29]), and their effect on species occurrence is often challenging to unveil. Nevertheless, these three characteristics were considered as it was hypothesised that an island's area, age and isolation affected these two species' occurrence.

2. Species' distribution within each island is driven by habitat characteristics and climate (island scale).

There is no historical data of bat occurrence in the Azores. Thus, it is not possible to evaluate the original habitat's effect on the colonisation of each island. Nevertheless, the current habitat is fundamental in defining each species' distribution and ability to sustain viable populations [2]. Although many species suffer severe impacts from land-cover change, other species adjust well or even benefit from human activities. Such can be the case of bat species that find roosting sites in buildings or exploit insect swarms around streetlamps [30,31]. Furthermore, the current climate can also have a profound effect on the distribution of species. Climate defines the species' physiological limits and the islands' primary productivity and, consequently, arthropod prey abundance (e.g., [32]). We thus hypothesised that climate would affect species' occurrence and that habitat use would differ among species, making different islands more suitable to one species than the other.

3. The two species co-occur less than would be expected by chance at both archipelago and island scales.

Another vital factor on species occurrence and the ability to keep a viable population on a restricted area is ecological interactions with other species. In the Azores, the nonmarine resident avifauna sums to less than two dozen [33]. Possible bat competitors, such as swifts or swallows, do not breed on the islands, and only one potential night predator is known, the long-eared owl (Asio otus) [34]. Domestic cats (Felis catus) occur in the islands, but they prey on bats opportunistically [35] and are not expected to predate both species differently. The spatial partitioning of feeding habitats is recognised as one of the primary mechanisms facilitating the coexistence of insectivorous bat species (reviewed by [36]). Larger species can exclude smaller ones from higher resource availability areas through interference competition (e.g., [37]). These interactions are expected to be even stronger when resources are limited [38]. Data on the distribution of co-occurring species can thus be assessed for evidence of interactions by examining whether species co-occur more or less than would be expected by chance $[39,40]$.

\section{Materials and Methods}

\subsection{Study Area}

The Azores is a remote archipelago of volcanic origin located of the middle ridges of the Atlantic North $\left(36-39^{\circ} \mathrm{N}, 24-31^{\circ} \mathrm{W}\right)$ at around $1400 \mathrm{~km}$ west of mainland Portugal (Figure 1) and $2200 \mathrm{~km}$ east of Newfoundland, close to the triple junction between the American, Eurasian and African tectonic plates. It is composed of nine main islands, usually 
referred by three groups: western (Flores and Corvo), central (Terceira, Faial, Pico, S. Jorge, and Graciosa) and eastern (S. Miguel and Santa Maria).

Originally, the archipelago was covered by Laurus (Laurisilva) and Juniperus forests [41,42], as well as Myrica faya thickets and pit bogs, but these habitats are currently found in very few areas. Several relict lake craters and small patches of natural vegetation are distributed in the islands. Human pressure has profoundly altered the land-cover of the islands that are now dominated by pastures and planted forests, mainly Cryptomeria japonica [43].

The archipelago climate is marine temperate, with low thermal amplitude, high precipitation and high air humidity [44]. There are climatic differences between islands, with average annual precipitation varying between $966 \mathrm{~mm}$ at Graciosa island and $2647 \mathrm{~mm}$ at Flores island [44]. This climate variability is associated with the islands' different ages and geomorphology, as the distance to the coast and altitude play essential roles in the local climate. Island size ranges from $17 \mathrm{~km}^{2}$ in Corvo to $745 \mathrm{~km}^{2}$ in S. Miguel.

\subsection{Bat Sampling}

Bats were sampled in point locations haphazardly distributed across the archipelago, ensuring a thorough sampling of each island's area and its most representative land uses. An exception to this was Pico island, where sampling was performed only up to an altitude of $1150 \mathrm{~m}$, excluding thus an area of ca. $15 \mathrm{~km}^{2}$ around the higher part of Pico Mountain (max. altitude $2530 \mathrm{~m}$ ).

Each sampled site was located as far apart as possible and the minimal inter-site distance was set to $500 \mathrm{~m}$ (range 503-6113 m, average $2173 \mathrm{~m}$ ) to avoid spatial correlation of the observations. Sampling was performed between March and September. It started half an hour after sunset and lasted the following three hours in nights with no rain, fog or strong winds. Bats were sampled through their echolocation calls using hand-held bat detectors (models D980 and D1000x, Pettersson Electronik). In each sampling point, a 10 min count was performed. During this period, the heterodyne was slowly swept back and forth between 20 and $60 \mathrm{kHz}$ to scan for bat activity. The high-frequency (HF) or time-expansion (TE) output was recorded whenever a bat-pass was detected [45], either using an external recorder (Creative Nomad Jukebox, DAP-6G01) or a memory card inbuilt in the bat detector. Light use was minimised during bat counts in non-urban areas to avoid any interference with bat occurrence and activity.

This methodology follows a previous study conducted in the islands by Rainho et al. [14], and the data collected during this first study were also included in the analysis. All nine islands were sampled in 2002 [14], 2003 and 2004. Species' distribution was further confirmed in S. Miguel (2011), S. Jorge and Pico (2012) and Graciosa and Terceira (2016). This study compiles 414 locations sampled between 2002 and 2016, covering all the nine islands of the archipelago. Each site was only considered once, even if sampled repeatedly in different years or nearby places $(<500 \mathrm{~m})$.

Recorded bat calls were analysed, and sound parameters were measured in Batsound (Pettersson Elektronik) using a sampling frequency of 48 and $348 \mathrm{kHz}$ (for TE and HF, respectively), 16 bits/sample and 1024 FFT with a Hanning window. Sound parameters of calls from N. azoreum and P. cf. maderensis generally have non-overlapping frequencies (see [14]). This separation enables a precise classification of the recorded calls using simple quantitative measures, namely the peak frequency $(\mathrm{kHz})$ and end frequency $(\mathrm{kHz})$.

\subsection{Data Analysis}

We investigated the potential role of several abiotic and biotic variables and biotic interactions as predictors of both species' presence at two scales: the archipelago and the island (Table A1). Graphical analysis was performed to explore the relationship between each predictor and bat occurrence and detect potential outliers. N. azoreum seems to be absent from the two most-isolated islands of the archipelago (Figure 1). For this reason, two variables were not considered in the analysis of this species' distribution: the UNEP index of island isolation, and the distance to the mainland. This is because both descriptors would perfectly explain the occurrence of this species in the archipelago. 
A Spearman correlation matrix was generated to check for collinearity between variables. The variables distance to Madeira archipelago and distance to the nearest island were excluded as they showed correlation values above 0.7 between them and with the distance to the mainland [46]. Two models for the occurrence of each species were adjusted using a different set of descriptors (Table A1): (i) archipelago-scale descriptors include: island size, age and isolation, and (ii) island-scale descriptors include land-use, altitude and vegetation indices, among others. Co-occurrence was considered in the models at both scales (Table A1).

Island-scale models were first adjusted using binomial Generalised Linear Mixed Models (GLMMs) with logit as a link function using the Lme4 R package [47]. Both island and year were tested as grouping variables. However, the random factor variance was zero for both grouping variables, so the models were adjusted instead using binominal Generalised Linear Models (GLMs) with logit as the link function. The effect of archipelago-scale variables was tested using univariate GLMs with the logit as the link function. Residuals were checked after fitting the models using normal probability histograms and QQ plots. These procedures did not reveal any severe violation of the assumptions of normality and homoscedasticity [48]. Goodness-of-fit was evaluated by comparing the null and residual deviances [48] and using the Area Under the Receiver Operator Characteristic (AUC) Curve [49,50]. Data analysis was performed in R environment [51]) using several packages: Multi-model Inference (MuMIn [52]), CAR [53], pROC [54], ggplot2 [55] and effects [56].

Spatial analysis and base maps were conducted using ArcGIS Desktop vs. 10.7.1 (ESRI, Redlands, CA, USA) with the cartographic information listed in Table A1. Significance was set at $p<0.05$.

\section{Results}

We conducted acoustic surveys at 414 sites across all nine islands, confirming $N$. azoreum in 161 sites at seven islands and P. cf. maderensis in 28 sites at six islands (Figure 1).

\subsection{Drivers of Occurrence at the Archipelago Scale}

No descriptor of size and isolation seems to justify the pattern of occurrence of $P$. cf. maderensis in the archipelago (Table 1). Even so, island size seems to be the best descriptor, suggesting that this species may favour smaller islands. Furthermore, for N. azoreum, none of the descriptors modelled seemed to be a significant driver of the occurrence of this species in the archipelago (Table 1). The exception is made to island isolation, measured either by the UNEP index or the distance to the mainland. These descriptors were not modelled because they perfectly separate the western group, Flores and Corvo (Figure 1), where N. azoreum was not observed. Although non-significant, island size may have some effect, with $N$. azoreum favouring large islands. One species' presence does not seem to drive the other's occurrence at this scale (Table 1).

\subsection{Drivers of Occurrence at the Island Scale}

The distribution of both species within the islands is, as expected, driven by habitat characteristics (Table 2). For P. cf. maderensis, the most important descriptors of occurrence were altitude and NDVI, with this species favouring lower altitudes and higher vegetation greenness. The best descriptor for N. azoreum distribution is land-cover, with this species favouring both urban areas and lagoons (Table 2). A significant negative relation was found, in both best models, with the distance to the nearest observation of the co-occurring species (Figure 2), showing that bats favour areas where the co-occurring species is present. 
Table 1. Parameters of the univariate GLM models relating bat occurrence and island characteristics. All variables are described in Table A1. The area under the ROC curve (AUC) is presented as a measure of adjustment of each model. The full models, including the intercept, are available, see Table A2.

\begin{tabular}{cccccc}
\hline & Estimate & St. Error & z Value & $p$ & AUC \\
\hline P. cf. maderensis & & & & & \\
\hline N.azor & -0.405 & 1.443 & -0.281 & 0.779 & 0.46 \\
Size & -0.007 & 0.005 & -1.422 & 0.155 & 0.83 \\
UNEP & 0.178 & 0.240 & 0.741 & 0.459 & 0.61 \\
DistPT & 0.006 & 0.005 & 1.056 & 0.291 & 0.72 \\
Island age & -0.065 & 0.293 & -0.222 & 0.825 & 0.39 \\
\hline N. azoreum & & & & & \\
\hline P.made & -0.406 & 1.443 & -0.281 & 0.779 & 0.45 \\
Size & 0.014 & 0.013 & 1.064 & 0.287 & 0.86 \\
Island age & 0.367 & 0.540 & 0.681 & 0.496 & 0.64 \\
\hline
\end{tabular}
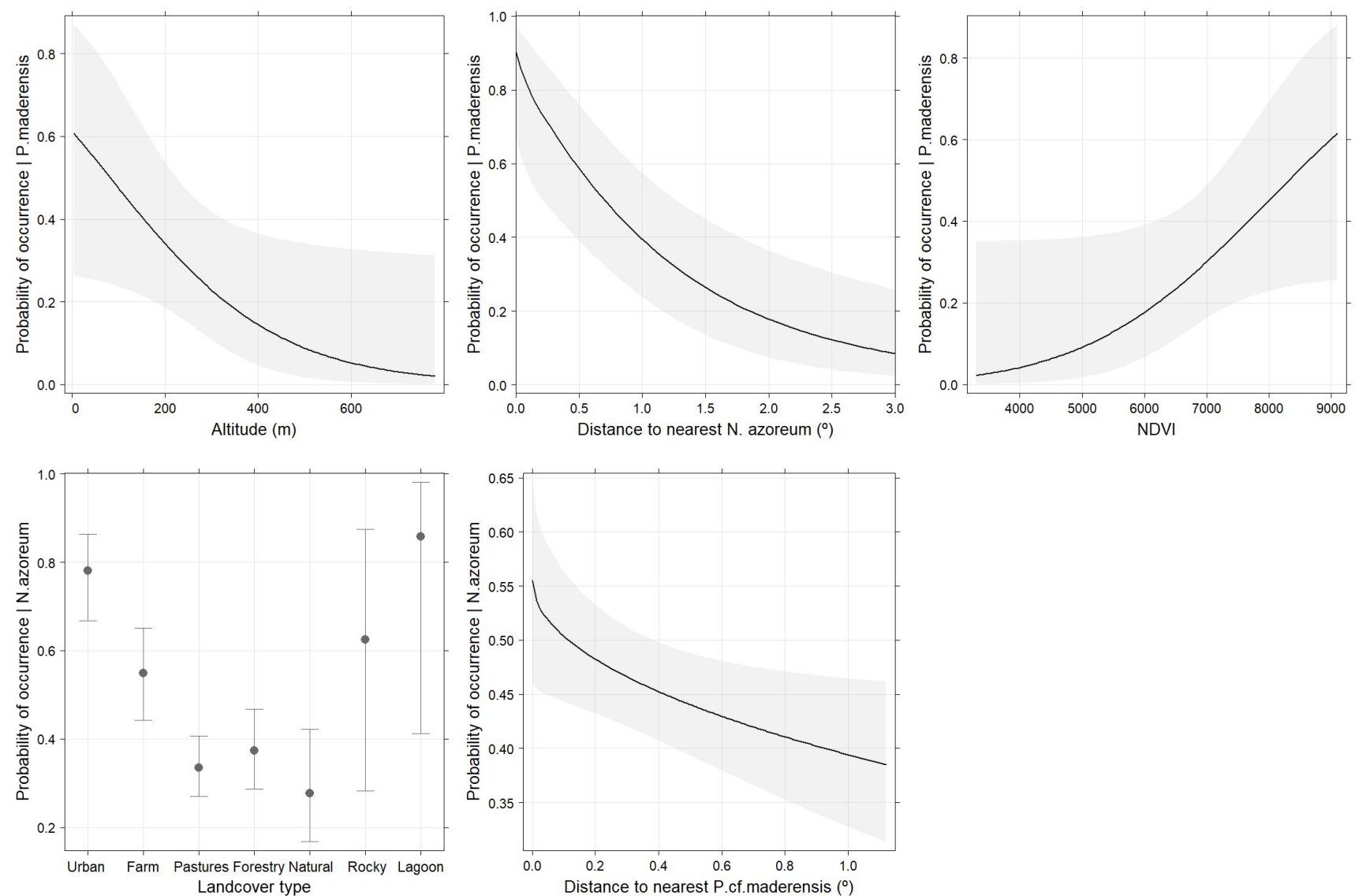

Figure 2. Binomial generalised linear models' partial effects of altitude, distance to the nearest $N$. azoreum and NDVI on the probability of the occurrence of $P$. cf. maderensis (top row) and land-cover and distance to the nearest $P$. $c f$. maderensis on the probability of the occurrence of $N$. azoreum (bottom row). Error bars and shaded areas represent 95 confidence intervals. 
Table 2. Parameters for the best candidate models for the distribution data of $P$. cf. maderensis (top) and $N$. azoreum (bottom) based on an information-theoretic approach using the Akaike information criterion for small samples (AICc). All variables are described in Table A1. The land-cover (LCo) descriptor uses urban areas as the indicator class. The area under the ROC curve (AUC) is presented as a measure of adjustment of each model.

\begin{tabular}{cccccc}
\hline & Estimate & St. Error & z Value & $p$ & AUC \\
\hline P. cf. maderensis & & & & & 0.883 \\
\hline Intercept & -5.589 & 2.656 & -1.314 & 0.189 & \\
Altitude & -0.006 & 0.003 & -2.007 & 0.045 & \\
DistNazor & -2.659 & 0.715 & -3.719 & 0.002 & \\
NDVI & 0.112 & 0.059 & 1.901 & 0.057 & \\
\hline N. azoreum & & & & & 0.673 \\
\hline Intercept & 1.723 & 0.360 & 4.800 & 0.000 & \\
LCo: farmland & -1.079 & 0.365 & -2.954 & 0.003 & \\
LCo: pastures & -1.963 & 0.334 & -5.864 & 0.000 & \\
LCo: forestry & -1.795 & 0.356 & -5.063 & 0.000 & \\
LCo: natural & -2.236 & 0.441 & -5.063 & 0.000 & \\
LCo: rocky & -1.043 & 0.736 & -1.417 & 0.156 & \\
LCo: lagoon & 0.525 & 1.137 & 0.462 & 0.644 & \\
DistPmade & -0.650 & 0.284 & -2.290 & 0.022 & \\
\hline
\end{tabular}

\section{Discussion}

Considering different scales, spatial dependencies and biotic interactions when analysing the distribution and patterns of co-occurring species proved to be an excellent strategy to understand the two species' distribution.

The archipelago-scale analysis revealed some difficulties, as the number of islands is reduced $(\mathrm{N}=9)$ and does not allow significant statistical levels to be easily reached. Furthermore, rarity approaches absence [57], raising the question of whether both species were present on every island, but we failed to detect them. The surveys performed were not exhaustive, and the restrictive distribution, particularly of $P$. $c f$. maderensis in some of the islands, may have limited our ability to detect its presence. Additionally, it will also be essential to assess whether there is seasonal variation in space use or even migration between islands, particularly in the central group $[18,58]$.

At the archipelago scale, it was confirmed that despite the high flight capacity of bats, isolation could limit some species' occurrence. The most remote islands (the western group) seem to be only occupied by P. cf. maderensis. This pattern seems somewhat surprising, given the much greater flight capacity of Nyctalus. However, although powerful flyers, some bat species seem to resist flying over large sections of saltwater [18,59], and P. cf. maderensis may prove to be a better disperser. In the Madeira archipelago where species of the two genera occur (P. maderensis and N. leisleri), only P. maderensis was recorded in Porto Santo, a smaller, more isolated island $[14,60]$. The Canary Islands are closer to the mainland, and both species occur in the most remote group of islands. However, while $P$. maderensis occurs in all four islands of this group, $N$. leisleri seems to only be present in the two larger ones [22,61].

The importance of other islands' characteristics as drivers of bat distribution and co-occurrence remains less clear. The size of the island seems to be important. A pattern was found in the Azores, albeit only almost significant, with P. cf. maderensis occupying smaller islands and N. azoreum larger ones. Only with a higher number of islands could the importance of this factor be clarified. The age of the island has high explanatory potential [28]. However, the knowledge on the Azores' geological dynamics is not yet sufficient to use this descriptor reliably while modelling the species' distribution.

As it was hypothesised, at the island scale, both land-cover and climate (as measured by primary production) proved to be essential drivers of bat species occurrence. Sampling was performed during the foraging period of both species, so this result should reflect 
the selection of areas with high prey availability. N. azoreum uses land-cover types where flying arthropods concentrate, such as water surfaces and areas with street lighting [14]. P. cf. maderensis showed no significant preference for any of the main land-cover of the islands, favouring coastal areas (lower altitude) with high primary productivity (high NDVI) [62]. The high availability of potential roosting sites in urban areas and lower altitude areas could also contribute to the observed habitat selection, even if the high diversity of roosts used by these species [63] weakens this hypothesis.

The biotic interactions proved to be fundamental in explaining the distribution and patterns of species co-occurrence [6]. At the archipelago scale, no significant co-occurrence pattern was found, either due to the scale of the analysis [6] or as a result of the small sample size. However, the co-occurring species' nearest presence was the factor with the highest explanatory capacity in the island-scale models. Contrary to what was hypothesised, the co-occurrence pattern does not suggest competition or the exclusion of one species by another. The pattern suggests a facilitation process instead since the probability of one species' occurrence is negatively and strongly dependent on the distance to the other species' occurrence in both species.

Biotic interactions are often hard to study outside experimental settings [39] and even more challenging when studying small, fast-flying nocturnal animals, such as bats. However, several studies reveal insectivorous bat competition and species exclusion in space and time when resources are limited [38,64]. References to bat-plant mutualism $[65,66]$ or cooperation between conspecifics are also frequent [67]. However, references to facilitation or even mutualism between different bat species are rare or non-existent.

Bat competition and resource partitioning are commonly invoked to explain different island bat species' distribution patterns [68], as well as diet [69,70]. An exception is the study by Sedlock and colleagues [71] in three islands of the Philippines. The authors compared four co-occurring species' foraging traits and diets in the islands. The results contradicted the expected hypothesis of resource partitioning, showing high diet overlap between sympatric species of distinct genera and different foraging-related traits [71]. These results raise interesting questions on the foraging strategies and possible interactions between these bat species.

Further research is necessary to clarify the mechanisms behind this apparent positive interaction between bat species. The ecology of both species is poorly known, and the genetic confirmation of the identity of the Pipistrellus is vital. However, among the mechanisms discussed in the literature, the optimal foraging theory provides the most plausible explanation for this facilitation. In regions where resources (e.g., prey arthropods) are scarce and their availability is highly variable in space or time, the best foraging strategy may depend on the rapid location of areas with a high concentration of prey. Locating and identifying these areas rapidly through the feeding buzzes of other individuals, of the same or another species, can be very advantageous. Bats' ability to eavesdrop the feeding buzzes of conspecifics is already recognised [72,73]. The higher similarity of the two species vocalisations compared with their ancestors [14] may have contributed to a higher overlap in the prey spectrum and the recognition of successful feeding activity between species.

Positive interspecific interactions (and even facilitation) between predators are known worldwide (e.g., $[74,75])$, but these are particularly well known among different species of marine seabirds and between these and some species of cetaceans, notably dolphins [74,76]. Marine predators also exploit prey that are locally abundant (schools of fish). The ubiquity of the association between these predators, which often use different and complementary foraging strategies, suggests that the benefits of exploiting the shoal together far outweigh the inevitable competition for prey [77]. Similarly, bat species with different echolocation calls, flight behaviour and ability to find prey can complement each other in searching for patchy prey. In addition, an increased number of bats will produce a high frequency of attacks on prey aggregation (e.g., a swarm of insects), which may result in a higher success rate among all predators, especially if attacks vary in direction in the three-dimensional space [78]. This may facilitate access to food and maximise foraging profit and, consequently, individuals' fitness [79]. 
This study provides a working hypothesis for future research into the potential mechanisms and impacts of biotic interaction on species' distribution, co-occurrence and conservation. Although N. azoreum seems stable on the islands where it occurs, its population is very fragmented. The situation of $P$. $c f$. maderensis is more dramatic, as its populations are minimal on all islands where it occurs. Both species are threatened and lack specific management and protection measures to ensure a good conservation status. Actions that warrant protecting their roosts, improving feeding habitats and reducing conflicts with humans are essential. However, preserving the interactions between co-occurring species may prove fundamental while managing and conserving both species and their ecosystems. If these bat species depend on one another for clues to find food, they can be highly vulnerable to population declines of the interacting species. Such declines can reach a point where they are no longer helpful to each other, with the consequent drops of their foraging success and, ultimately, their survival.

Funding: The author was supported by the Portuguese Foundation for Science and Technology (FCT) grants SFRH/BD/23800/2005 and SFRH/BPD/101983/2014.

Institutional Review Board Statement: Not applicable.

Informed Consent Statement: Not applicable.

Data Availability Statement: The datasets generated during the current study are available in the repository for the Portuguese National Reports for Article 17 of the EU Habitats Directive. https:/ / geocatalogo.icnf.pt/websig/, accessed on 20 August 2016.

Acknowledgments: I would like to thank the Direção Regional de Ambiente dos Açores and Instituto da Conservação da Natureza e das Florestas for all the support provided during my several visits to the islands. To Amigos dos Açores, namely to Carmo Barreto, for their interest in bats and for supporting my trip to S. Miguel in 2011. Furthermore, to all who helped me during the fieldwork: Carla Goulart da Silva, Joaquim Teodósio, João Monteiro, Aniceto Cordeiro, Valter Medeiros, Mário Silva, Helder Fraga and Luís Filipe Correia. One last word to Jorge M. Palmeirim and J. Tiago Marques who took the first steps of studying bats with me in the Azores. Thanks!

Conflicts of Interest: The author declares no conflict of interest.

\section{Appendix A}

Table A1. Description of the predictor variables used in species distribution models and the data sources from which they were derived.

\begin{tabular}{|c|c|c|}
\hline Descriptor (Acronym) & Type, Units, and Classes & Data Source and Scale \\
\hline \multicolumn{3}{|l|}{ Archipelago-scale descriptors } \\
\hline Island size (Size) & $\begin{array}{l}\text { Terrestrial area of each island. } \\
\text { Continuous, ranging from } 17 \text { to } 745 \mathrm{~km}^{2}\end{array}$ & $\begin{array}{c}\text { Derived from CAOP 2016-Official } \\
\text { Administrative Divisions of Portugal [80]. } \\
2016 \text { Vectorial 1:25,000. }\end{array}$ \\
\hline Distance to the mainland (DistPT) & $\begin{array}{l}\text { The minimum distance between the } \\
\text { coastline of each island and the coastline } \\
\text { of the Portuguese mainland. Continuous, } \\
\text { ranging from } 1367 \text { to } 1865 \mathrm{~km}\end{array}$ & Ditto [80] \\
\hline Distance to the nearest island (DistISL) & $\begin{array}{l}\text { The minimum distance between the } \\
\text { coastline of each island and the coastline } \\
\text { of the nearest island. Continuous, } \\
\text { ranging from } 5.9 \text { to } 80.1 \mathrm{~km}\end{array}$ & Ditto [80] \\
\hline
\end{tabular}


Table A1. Cont.

\begin{tabular}{|c|c|c|}
\hline Descriptor (Acronym) & Type, Units, and Classes & Data Source and Scale \\
\hline Distance to Madeira (DistMAD) & $\begin{array}{c}\text { The minimum distance between each } \\
\text { island's coastline and the coastline of } \\
\text { Madeira island (see Figure 1). } \\
\text { Continuous, ranging from } 840 \text { to } \\
1439 \mathrm{~km} \text {. }\end{array}$ & Ditto [80] \\
\hline UNEP isolation index (UNEP) & $\begin{array}{l}\text { A measure of the isolation of the island } \\
\text { from potential sources of colonisation. } \\
\text { Continuous, ranging from } 75 \text { to } 96 .\end{array}$ & $\begin{array}{c}\text { Retrieved from Island } \\
\text { Directory-UNEP/WCMC. Index per } \\
\text { island. [81] }\end{array}$ \\
\hline Island age & $\begin{array}{c}\text { The maximum geological age of each } \\
\text { island. Continuous, ranging from } 0.27 \text { to } \\
8.12 \mathrm{Ma} \text {. }\end{array}$ & Value per island [82]. \\
\hline Species' occurrence (Nazor or Pmade) & $\begin{array}{c}\text { Information on if each species was } \\
\text { detected or not on each island. Binomial } \\
{[0-1]}\end{array}$ & This study and Rainho et al. [14] \\
\hline
\end{tabular}

Altitude Altitude a.s.l. Continuous, ranging from 0 to $1150 \mathrm{~m}$
Derived from SRTM 90 m DEM [83] and

validated using official cartography [84]. Raster 90 m.

\begin{tabular}{|c|c|c|}
\hline Land-cover (LCo) & $\begin{array}{c}\text { Includes all key land-cover types of the } \\
\text { archipelago. Categorical: Urban, farm, } \\
\text { pastures, forestry, natural, rocky } \\
\text { and lagoon }\end{array}$ & $\begin{array}{l}\text { Retrieved from [85] and validated in t } \\
\text { field. } 2007 \text { Vectorial 1:15,000. }\end{array}$ \\
\hline NDVI & $\begin{array}{l}\text { 16-days Normalised Difference } \\
\text { vegetation Index-a measure of green } \\
\text { biomass. Continuous, ranging from } 0 \text { to } \\
9201 \text { (valid data ranging from } \\
\quad-2000 \text { to } 10,000 \text { ) }\end{array}$ & $\begin{array}{l}\text { Derived from Modis } 500 \text { m 16-days } \\
\text { imagery [86]. June } 2015 \text { Raster } 500 \text { m }\end{array}$ \\
\hline Distance to the coast (DistCoast) & $\begin{array}{l}\text { Distance between the site sampled and } \\
\text { the nearest coastline of the island. } \\
\text { Continuous, ranging from } 0 \text { to } 7500 \mathrm{~m}\end{array}$ & $\begin{array}{c}\text { Derived from CAOP2016 [80]. } 2016 \\
\text { Vectorial 1:25,000. }\end{array}$ \\
\hline $\begin{array}{l}\text { Distance to P made/Nazor } \\
\text { (DistPmade/DistNazor) }\end{array}$ & $\begin{array}{c}\text { Distance to the nearest site where the } \\
\text { presence of the co-occurring species was } \\
\text { detected. Continuous, ranging from } \\
0 \text { to } 2.58616^{\circ}\end{array}$ & This study and Rainho et al. [14]. \\
\hline
\end{tabular}

Table A2. Parameters of the univariate GLM full models (including intercept) relating island characteristics and the occurrence of P. cf. maderensis (top) and N. azoreum (bottom). All variables are described in Table A1. Nazor and Pmade are binomial categorical variables with absence as reference.

\begin{tabular}{ccccc}
\hline & Estimate & Std. Error & $\mathbf{z}$ Value & $\operatorname{Pr}(>|\mathbf{z}|)$ \\
\hline Pipistrellus cf. maderensis & & & & \\
\hline & 0.6931 & 1.2247 & 0.566 & 0.571 \\
Nazor(1) & -0.4055 & 1.4434 & -0.281 & 0.779 \\
\hline \multirow{2}{*}{ Size } & 2.6240 & 1.6163 & 1.623 & 0.104 \\
UNEP & -0.0070 & 0.0048 & -1.422 & 0.155 \\
\hline & -13.4913 & 18.9379 & -0.712 & 0.476 \\
DistPT & 0.1781 & 0.2404 & 0.741 & 0.459 \\
\hline \multirow{2}{*}{ Island age } & -8.2110 & 8.3459 & -0.984 & 0.325 \\
& 0.0056 & 0.0053 & 1.056 & 0.291 \\
\hline
\end{tabular}


Table A2. Cont.

\begin{tabular}{ccccc}
\hline & Estimate & Std. Error & $\mathbf{z}$ Value & $\operatorname{Pr}(>|\mathbf{z}|)$ \\
\hline Nyctalus azoreum & & & & \\
\hline \multirow{2}{*}{ Pmade(1) } & 1.0986 & 1.1547 & 0.951 & 0.341 \\
Size & -0.4055 & 1.4434 & -0.281 & 0.779 \\
\hline & -0.8788 & 1.6688 & -0.527 & 0.598 \\
Island age & 0.0145 & 0.0136 & 1.064 & 0.287 \\
\hline
\end{tabular}

\section{References}

1. Fletcher, R.; Fortin, M.J. Introduction to Spatial Ecology and Its Relevance for Conservation. In Spatial Ecology and Conservation Modeling: Applications with R; Fletcher, R., Fortin, M.J., Eds.; Springer International Publishing: Cham, Switzerland, 2018; Chapter 1, pp. 1-13.

2. Hirzel, A.H.; Le Lay, G. Habitat suitability modelling and niche theory. J. Appl. Ecol. 2008, 45, 1372-1381. [CrossRef]

3. Salinas-Ramos, V.; Ancillotto, L.; Cistrone, L.; Nastasi, C.; Bosso, L.; Smeraldo, S.; Cordero, V.; Russo, D. Artificial illumination influences niche segregation in bats. Environ. Pollut. 2021, 284, 117187. [CrossRef] [PubMed]

4. Wang, A.; Melton, A.E.; Soltis, D.E.; Soltis, P.S. Potential distributional shifts in North America of allelopathic invasive plant species under climate change models. Plant Divers. 2021. [CrossRef]

5. Santos, H.; Juste, J.; Ibáñez, C.; Palmeirim, J.M.; Godinho, R.; Amorim, F.; Alves, P.; Costa, H.; de Paz, O.; Pérez-Suarez, G.; et al. Influences of ecology and biogeography on shaping the distributions of cryptic species: Three bat tales in Iberia. Biol. J. Linn. Soc. 2014, 112, 150-162. [CrossRef]

6. Wisz, M.S.; Pottier, J.; Kissling, W.D.; Pellissier, L.; Lenoir, J.; Damgaard, C.F.; Dormann, C.F.; Forchhammer, M.C.; Grytnes, J.; Guisan, A. The role of biotic interactions in shaping distributions and realised assemblages of species: Implications for species distribution modelling. Biol. Rev. 2013, 88, 15-30. [CrossRef] [PubMed]

7. Rota, C.T.; Ferreira, M.A.R.; Kays, R.W.; Forrester, T.D.; Kalies, E.L.; McShea, W.J.; Parsons, A.W.; Millspaugh, J.J. A multispecies occupancy model for two or more interacting species. Methods Ecol. Evol. 2016, 7, 1164-1173. [CrossRef]

8. Lewis, J.S.; Farnsworth, M.L.; Burdett, C.L.; Theobald, D.M.; Gray, M.; Miller, R.S. Biotic and abiotic factors predicting the global distribution and population density of an invasive large mammal. Sci. Rep. 2017, 7, 44152. [CrossRef] [PubMed]

9. Whittaker, R.J.; Fernández-Palacios, J.M. Island Biogeography: Ecology, Evolution, and Conservation, 2nd ed.; Oxford University Press: Oxford, UK, 2007.

10. Conenna, I.; Rocha, R.; Russo, D.; Cabeza, M. Insular bats and research effort: A review of global patterns and priorities. Mammal Rev. 2017, 47, 169-182. [CrossRef]

11. Bosso, L.; Mucedda, M.; Fichera, G.; Kiefer, A.; Russo, D. A gap analysis for threatened bat populations on Sardinia. Hystrix Ital. J. Mammal. 2016, 27, 212-214.

12. Palmeirim, J.M. A morphometric assessment of the systematic position of the Nyctalus from Azores and Madeira (Mammalia:Chiroptera). Mammalia 1991, 55, 381-388. [CrossRef]

13. Trujillo, D.; Gonzalez, C. Pipistrellus maderensis (Dobson, 1878), (Chiroptera: Vespertilionidae) a new addition to the Azorean fauna (Atlantic Ocean). Vieraea 2011, 39, 215-218.

14. Rainho, A.; Marques, J.; Palmeirim, J. Os Morcegos dos Arquipélagos dos Açores e da Madeira: Um Contributo Para a Sua Conservação; Instituto da Conservação da Natureza: Lisboa, Portugal, 2002; p. 49.

15. Hutson, A.; Aulagnier, S.; Rainho, A.; Palmeirim, J. Nyctalus azoreum. In The IUCN Red List of Threatened Species; e.T14922A4475157; 2008. Available online: https://www.researchgate.net/publication/295260102_Nyctalus_azoreum (accessed on 22 January 2016)

16. Speakman, J.R.; Webb, P.I. Taxonomy, status and distribution of the Azorean bat (Nyctalus azoreum). J. Zool. 1993, 231, 27-38. [CrossRef]

17. Irwin, N.R.; Speakman, J.R. Azorean bats Nyctalus azoreum, cluster as they emerge from roosts, despite the lack of avian predators. Acta Chiropterologica 2003, 5, 185-192. [CrossRef]

18. Salgueiro, P.; Coelho, M.M.; Palmeirim, J.M.; Ruedi, M. Mitochondrial DNA variation and population structure of the island endemic Azorean bat (Nyctalus azoreum). Mol. Ecol. 2004, 13, 3357-3366. [CrossRef] [PubMed]

19. Salgueiro, P.; Palmeirim, J.M.; Ruedi, M.; Coelho, M.M. Gene flow and population structure of the endemic Azorean bat (Nyctalus azoreum) based on microsatellites: Implications for conservation. Conserv. Genet. 2008, 9, 1163-1171. [CrossRef]

20. Skiba, R. Nachweis einer Zwergfleder-maus Pipistrellus pipistrellus (Schreber, 1774), auf der Azorinsel Flores (Portugal). Myotis 1996, 34, 81-84.

21. Cabral, M.J.C.; Almeida, J.; Almeida, P.R.; Dellinger, T.; Ferrand de Almeida, N.; Oliveira, M.E.; Palmeirim, J.M.; Queiroz, A.I.; Rogado, L.; Santos-Reis, M. Livro Vermelho dos Vertebrados de Portugal, 1st ed.; Instituto da Conservação da Natureza: Lisboa, Portugal, 2005; p. 660. 
22. Alcaldé, J.; Juste, J. Pipistrellus maderensis. In The IUCN Red List of Threatened Species 2016; e.T17315A1380378; 2016. Available online: https:/ / www.iucnredlist.org/species/17315/1380378 (accessed on 22 August 2017).

23. Piraccini, R. Nyctalus azoreum. In The IUCN Red List of Threatened Species 2016; e.T14922A546843; 2016. Available online: https:/ / www.iucnredlist.org/species/14922/546843 (accessed on 22 August 2017).

24. MacArthur, R.H.; Wilson, E.O. The Theory of Island Biogeography; Princeton University Press: Priceton, NJ, USA, 1967.

25. Fernández-Palacios, J.M. Shaped by sea-level shifts. Nature 2016, 532, 42-43. [CrossRef] [PubMed]

26. Speer, K.A.; Petronio, B.J.; Simmons, N.B.; Richey, R.; Magrini, K.; Soto-Centeno, J.A.; Reed, D.L. Population structure of a widespread bat (Tadarida brasiliensis) in an island system. Ecol. Evol. 2017, 7, 7585-7598. [CrossRef] [PubMed]

27. Fleming, T.H. Bat Migration. Encycl. Anim. Behav. 2019, 2019, 605-610.

28. Whittaker, R.J.; Fernández-Palacios, J.M.; Matthews, T.J.; Borregaard, M.K.; Triantis, K.A. Island biogeography: Taking the long view of nature's laboratories. Science 2017, 357, eaam8326. [CrossRef]

29. Ramalho, R.S.; Helffrich, G.; Madeira, J.; Cosca, M.; Thomas, C.; Quartau, R.; Hipólito, A.; Rovere, A.; Hearty, P.J.; Ávila, S.P. Emergence and evolution of Santa Maria Island (Azores)? The conundrum of uplifted islands revisited. Bulletin 2017, 129, 372-390. [CrossRef]

30. Schoeman, M. Light pollution at stadiums favors urban exploiter bats. Anim. Conserv. 2016, 19, 120-130. [CrossRef]

31. Spoelstra, K.; van Grunsven, R.H.; Ramakers, J.J.; Ferguson, K.B.; Raap, T.; Donners, M.; Veenendaal, E.M.; Visser, M.E. Response of bats to light with different spectra: Light-shy and agile bat presence is affected by white and green, but not red light. Proc. $R$. Soc. B Biol. Sci. 2017, 284, 20170075. [CrossRef] [PubMed]

32. Birkhofer, K.; Wolters, V. The global relationship between climate, net primary production and the diet of spiders. Glob. Ecol. Biogeogr. 2012, 21, 100-108. [CrossRef]

33. Coelho, R.; Vieira, A. Aves dos Açores. 2020. Available online: https://avesdosazores.wordpress.com (accessed on 22 August 2020).

34. Speakman, J.R. The impact of predation by birds on bat populations in the British Isles. Mammal Rev. 1991, 21, 123-142. [CrossRef]

35. Khayat, R.O.S.; Grant, R.A.; Ryan, H.; Melling, L.M.; Dougill, G.; Killick, D.R.; Shaw, K.J. Investigating cat predation as the cause of bat wing tears using forensic DNA analysis. Ecol. Evol. 2020, 10, 8368-8378. [CrossRef]

36. Patterson, B.D.; Willig, M.R.; Stevens, R.D. Trophic strategies, niche partitioning, and patterns of ecological organization. In Bat Ecology; Kunz, T.H., Fenton, M.B., Eds.; The University of Chicago Press: Chicago, IL, USA, 2003; Chapter 12, pp. 536-557.

37. Richmond, O.M.W.; Hines, J.E.; Beissinger, S.R. Two-species occupancy models: A new parameterization applied to co-occurrence of secretive rails. Ecol. Appl. 2010, 20, 2036-2046. [CrossRef]

38. Razgour, O.; Korine, C.; Saltz, D. Does interspecific competition drive patterns of habitat use in desert bat communities? Oecologia 2011, 167, 493-502. [CrossRef]

39. Haynes, T.B.; Schmutz, J.A.; Lindberg, M.S.; Wright, K.G.; Uher-Koch, B.D.; Rosenberger, A.E. Occupancy of yellow-billed and Pacific loons: Evidence for interspecific competition and habitat mediated co-occurrence. J. Avian Biol. 2014, 45, 296-304. [CrossRef]

40. Rainho, A.; Palmeirim, J.M. Understanding the long term consequences of fragmentation: Lessons from the bats of Bijagós (Guinea-Bissau, West Africa). Hystrix 2017, 28, 173-179.

41. Fernández-Palacios, J.M.; de Nascimento, L.; Otto, R.; Delgado, J.D.; García-del Rey, E.; Arévalo, J.R.; Whittaker, R.J. A reconstruction of Palaeo-Macaronesia, with particular reference to the long-term biogeography of the Atlantic island laurel forests. J. Biogeogr. 2011, 38, 226-246. [CrossRef]

42. Elias, R.B.; Gil, A.; Silva, L.; Fernández-Palacios, J.M.; Azevedo, E.B.; Reis, F. Natural zonal vegetation of the Azores Islands: Characterization and potential distribution. Phytocoenologia 2016, 46, 107-123. [CrossRef]

43. Monteiro, R.; Furtado, S.; Rocha, M.; Freitas, M.; Medeiros, R.; Cruz, J. O Ordenamento do Território nos Açores: Política e Instrumentos, Secretaria Regional do Ambiente e do Mar, Direcção Regional do Ordenamento do Território e dos Recursos Hídricos: Ponta Delgada, Portugal, 2008.

44. Cruz, J.V. Groundwater and volcanoes: Examples from the Azores archipelago. Environ. Geol. 2003, 44, 343-355. [CrossRef]

45. Fenton, M.B. A technique for monitoring bat activity with results obtained from different environments in southern Ontario. Can. J. Zool. 1970, 48, 847-851. [CrossRef]

46. Tabachnick, B.; Fidell, L. Using Multivariate Statistics, 3rd ed.; HarperCollins Publishers: New York, NY, USA, $1996 ;$ p. 880.

47. Bates, D.; Mächler, M.; Bolker, B.; Walker, S. Fitting linear mixed-effects models using lme4. J. Stat. Softw. 2015, 67, 1-48. [CrossRef]

48. Dobson, A.J. An Introduction to Generalized Linear Models, 2nd ed.; Texts in Statistical Science; Chapman \& Hall/CRC: Boca Raton, FL, USA, 2002; p. 221.

49. Smeraldo, S.; Bosso, L.; Salinas-Ramos, V.B.; Ancillotto, L.; Sánchez-Cordero, V.; Gazaryan, S.; Russo, D. Generalists yet different: Distributional responses to climate change may vary in opportunistic bat species sharing similar ecological traits. Mammal Rev. 2021, 51, 571-584. [CrossRef]

50. Delgado-Jaramillo, M.; Aguiar, L.M.; Machado, R.B.; Bernard, E. Assessing the distribution of a species-rich group in a continental-sized megadiverse country: Bats in Brazil. Divers. Distrib. 2020, 26, 632-643. [CrossRef]

51. R Core Team. R: A Language and Environment for Statistical Computing; R Foundation for Statistical Computing: Vienna, Austria, 2020.

52. Barton, K. MuMIn: Multi-Model Inference; R Package Version 1.43.0; R Foundation for Statistical Computing: Vienna, Austria, 2018 
53. Fox, J.; Weisberg, S. An R Companion to Applied Regression, 3rd ed.; Sage: Thousand Oaks, CA, USA, 2019.

54. Robin, X.; Turck, N.; Hainard, A.; Tiberti, N.; Lisacek, F.; Sanchez, J.C.; Müller, M. pROC: An open-source package for R and S+ to analyze and compare ROC curves. BMC Bioinform. 2011, 12, 77. [CrossRef]

55. Wickham, H. ggplot2: Elegant Graphics for Data Analysis; Springer: New York, NY, USA, 2016.

56. Fox, J.; Weisberg, S. Visualizing fit and lack of fit in complex regression models with predictor effect plots and partial residuals. J. Stat. Softw. 2018, 87, 1-27. [CrossRef]

57. McCracken, G.F.; Hayes, J.P.; Cevallos, J.; Guffey, S.Z.; Romero, F.C. Observations on the distribution, ecology, and behaviour of bats on the Galapagos Islands. J. Zool. 1997, 243, 757-770. [CrossRef]

58. Smeraldo, S.; Di Febbraro, M.; Bosso, L.; Flaquer, C.; Guixé, D.; Lisón, F.; Meschede, A.; Juste, J.; Prüger, J.; Puig-Montserrat, X.; et al. Ignoring seasonal changes in the ecological niche of non-migratory species may lead to biases in potential distribution models: Lessons from bats. Biodivers. Conserv. 2018, 27, 2425-2441. [CrossRef]

59. Castella, V.; Ruedi, M.; Excoffier, L.; Ibáñez, C.; Arlettaz, R.; Hausser, J. Is the Gibraltar Strait a barrier to gene flow for the bat Myotis myotis (Chiroptera: Vespertilionidae)? Mol. Ecol. 2000, 9, 1761-1772. [CrossRef] [PubMed]

60. Jesus, J.; Teixeira, S.; Freitas, T.; Teixeira, D.; Brehm, A. Genetic identity of Pipistrellus maderensis from the Madeira archipelago: A first assessment, and implications for conservation. Hystrix 2013, 177-180.

61. Juste, J.; Paunovic, M. Nyctalus leisleri. In The IUCN Red List of Threatened Species 2016; e.T14919A22016159; 2016. Available online: https:/ / www.iucnredlist.org/species/14919/22016159 (accessed on 22 August 2017).

62. Pettorelli, N.; Gaillard, J.M.; Mysterud, A.; Duncan, P.; Chr. Stenseth, N.; Delorme, D.; Van Laere, G.; Toïgo, C.; Klein, F. Using a proxy of plant productivity (NDVI) to find key periods for animal performance: The case of roe deer. Oikos 2006, 112, 565-572. [CrossRef]

63. Palmeirim, J.M.; Rodrigues, L.; Rainho, A.; Ramos, M.J. Chiroptera. In Guia dos Mamíferos Terrestres de Portugal Continental, Açores e Madeira; Mathias, M.L., Ed.; Instituto da Conservação da Natureza, Centro de Biologia Ambiental da Universidade de Lisboa: Lisboa, Portugal, 1999; Chapter 4, pp. 41-96.

64. Roeleke, M.; Johannsen, L.; Voigt, C.C. How bats escape the Competitive Exclusion Principle-Seasonal shift from intraspecific to interspecific competition drives space use in a bat ensemble. Front. Ecol. Evol. 2018, 6, 101. [CrossRef]

65. Schöner, C.R.; Schöner, M.G.; Grafe, T.U.; Clarke, C.M.; Dombrowski, L.; Tan, M.C.; Kerth, G. Ecological outsourcing: A pitcher plant benefits from transferring pre-digestion of prey to a bat mutualist. J. Ecol. 2017, 105, 400-411. [CrossRef]

66. Moreno, S.A.; Gelambi, M.; Biganzoli, A.; Molinari, J. Small nutrient molecules in fruit fuel efficient digestion and mutualism with plants in frugivorous bats. Sci. Rep. 2019, 9, 19376. [CrossRef]

67. Wilkinson, G.S.; Carter, G.G.; Bohn, K.M.; Adams, D.M. Non-kin cooperation in bats. Philos. Trans. R. Soc. B Biol. Sci. 2016, 371, 20150095. [CrossRef]

68. Russo, D.; Di Febbraro, M.; Rebelo, H.; Mucedda, M.; Cistrone, L.; Agnelli, P.; De Pasquale, P.P.; Martinoli, A.; Scaravelli, D.; Spilinga, C.; et al. What Story Does Geographic Separation of Insular Bats Tell? A Case Study on Sardinian Rhinolophids. PLoS ONE 2014, 9, e110894. [CrossRef] [PubMed]

69. Fukui, D.; Okazaki, K.; Maeda, K. Diet of three sympatric insectivorous bat species on Ishigaki Island, Japan. Endanger. Species Res. 2009, 8, 117-128. [CrossRef]

70. Emrich, M.A.; Clare, E.L.; Symondson, W.O.; Koenig, S.E.; Fenton, M.B. Resource partitioning by insectivorous bats in Jamaica. Mol. Ecol. 2014, 23, 3648-3656. [CrossRef] [PubMed]

71. Sedlock, J.L.; Krüger, F.; Clare, E.L. Island bat diets: Does it matter more who you are or where you live? Mol. Ecol. 2014, 23, 3684-3694. [CrossRef] [PubMed]

72. Fenton, M.B. Eavesdropping on the echolocation and social calls of bats. Mammal Rev. 2003, 33, 193-204. [CrossRef]

73. Gillam, E. Eavesdropping by bats on the feeding buzzes of conspecifics. Can. J. Zool. 2007, 85, 795-801. [CrossRef]

74. Goyert, H.F.; Manne, L.L.; Veit, R.R. Facilitative interactions among the pelagic community of temperate migratory terns, tunas and dolphins. Oikos 2014, 123, 1400-1408. [CrossRef]

75. Losey, J.E.; Denno, R.F. Positive predator-predator interactions: Enhanced predation rates and synergistic suppression of aphid populations. Ecology 1998, 79, 2143-2152.

76. Boyd, C.; Grünbaum, D.; Hunt, G.L., Jr.; Punt, A.E.; Weimerskirch, H.; Bertrand, S. Effects of variation in the abundance and distribution of prey on the foraging success of central place foragers. J. Appl. Ecol. 2017, 54, 1362-1372. [CrossRef]

77. Veit, R.R.; Harrison, N.M. Positive Interactions among Foraging Seabirds, Marine Mammals and Fishes and Implications for Their Conservation. Front. Ecol. Evol. 2017, 5, 121. [CrossRef]

78. Lett, C.; Semeria, M.; Thiebault, A.; Tremblay, Y. Effects of successive predator attacks on prey aggregations. Theor. Ecol. 2014, 7, 239-252. [CrossRef]

79. Sinervo, B. Optimal Foraging Theory: Constraints and Cognitive Processes. In Behavioral Ecology; University of California: Santa Cruz, CA, USA, 1997; pp. 105-130.

80. DGT. CAOP-Carta Administrativa Oficial de Portugal-Açores, Grupos Central. Oriental e Ocidental. 2016. Available online: https:/ / www.dgterritorio.gov.pt/cartografia/cartografia-tematica/caop?language=en (accessed on 28 December 2016).

81. Dahl, A.L. Island Directory, UNEP/WCMC. 2010. Available online: http://islands.unep.ch/Tisolat.htm (accessed on 28 December 2016).

82. França, Z.; Cruz, J.V.; Nunes, J.C.; Forjaz, V. Geologia dos Açores: Uma perspectiva actual. Açoreana 2003, 10, 11-140. 
83. Jarvis, A.; Reuter, H.I.; Nelson, A.; Guevara, E. Hole-Filled SRTM for the Globe Version 4. CGIAR Consortium for Spatial Information. 2008. Available online: http://srtm.csi.cgiar.org/ (accessed on 28 December 2016).

84. IGeoE; DROTRH. Curvas de nível das Ilhas dos Açores. In Cartografia Vectorial Produzida à Escala 1:25,000 Pelo; Instituto Geográfico do Exército (IGeoE) com Actualizações da Direcção Regional do Ordenamento do Território e Recursos Hídricos (DROTRH): Horta, Portugal, 2000.

85. DROTRH. Carta de Ocupação do solo da Região Autónoma dos Açores. Cartografia Produzida com Base nas Imagens de Satélite-LANDSAT7; Direcção Regional do Ordenamento do Território e Recursos Hídricos (DROTRH): Lisboa, Portugal, 2007.

86. Didan, K. MOD13A1 MODIS/Terra Vegetation Indices 16-Day L3 Global 500 m SIN Grid V006. 2015. Available online: https:/ /lpdaac.usgs.gov/products/mod13a1v006/ (accessed on 28 December 2016). 